\title{
Community interventions related to intimate partner violence among adolescents: scope review
}

\author{
Intervenções comunitárias relacionadas à violência entre parceiros íntimos adolescentes: revisão de escopo
}

Intervenciones comunitarias relacionadas con la violencia entre compañeros íntimos adolescentes: una revisión de alcance

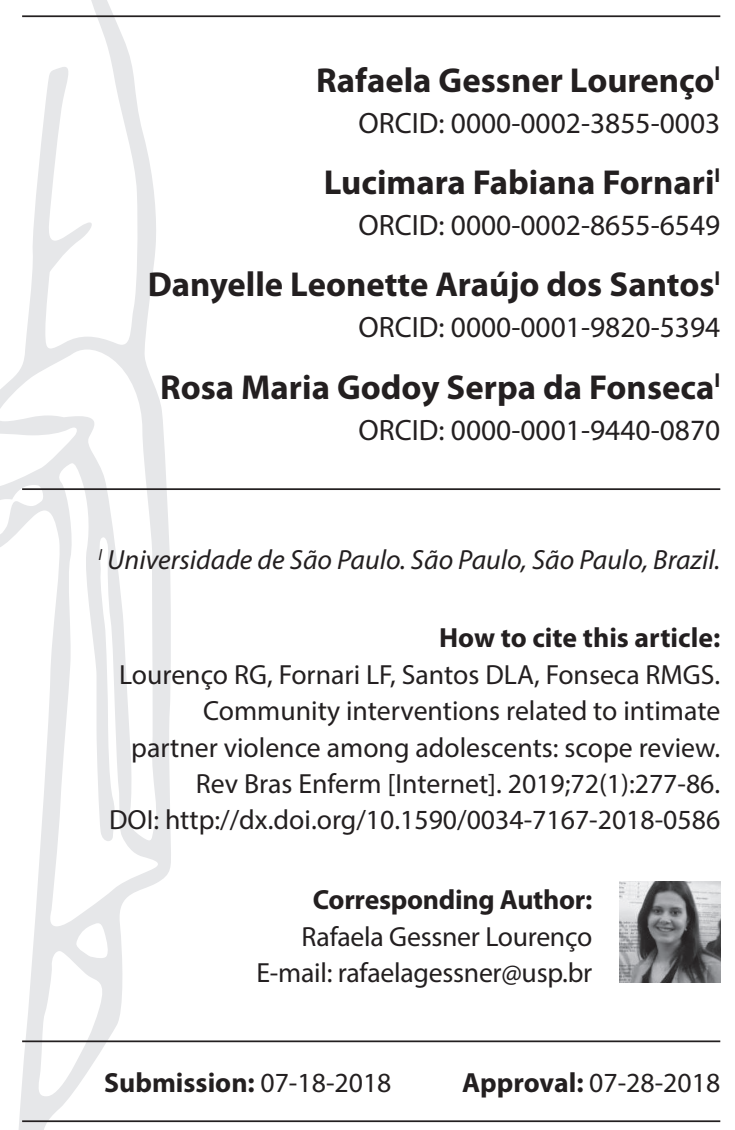

\section{ABSTRACT}

Objective: To map the successful experiences of interventions aimed at coping with violence among intimate partners in adolescence, in the light of the gender and generation categories. Method: Scope review carried out in the MEDLINE, CINAHL, Scopus and PsycINFO databases. We selected primary, empirical, quantitative and qualitative studies published in three languages. Results: From the 3,234 articles found, 31 made up the review. Most of the interventions were carried out at the school level, with focus of interest in developing skills to maintain healthy relationships; types of violence; knowledge of non-violent alternatives to conflict resolution; resources to assist those involved; and role of friends as interveners. Final considerations: Interventions to confront this phenomenon can modify the affective and sexual relationships in adolescence. In addition to the generation category, the actions should incorporate the gender perspective, related to the processes of construction of femininity and masculinity.

Descriptors: Adolescents; Intimate Partner Violence; Review; Strategies; Nursing.

\section{RESUMO}

Objetivo: Mapear as experiências exitosas das intervenções direcionadas ao enfrentamento da violência entre parceiros íntimos na adolescência, à luz das categorias gênero e geração. Método: Revisão de escopo realizada nas bases de dados MEDLINE, CINAHL, Scopus e PsycINFO. Foram selecionados estudos primários, empíricos, quantitativos e qualitativos, publicados em três idiomas. Resultados: Dos 3.234 artigos encontrados, 31 compuseram a revisão. A maioria das intervenções foi realizada no âmbito escolar, com focos de interesse em desenvolvimento de habilidades para manutenção de relacionamentos saudáveis; tipos de violência; conhecimento de alternativas não violentas para a resolução de conflitos; recursos para auxílio aos envolvidos; e papel dos amigos como interventores. Considerações finais: As intervenções para o enfrentamento desse fenômeno podem modificar os relacionamentos afetivos e sexuais na adolescência. Além da categoria geracional, as ações devem incorporar a perspectiva de gênero, relacionada aos processos de construção de feminilidade e masculinidade. Descritores: Adolescentes; Violência entre Parceiros Íntimos; Revisão; Estratégias; Enfermagem.

\section{RESUMEN}

Objetivo: Mapear experiencias exitosas de intervenciones dirigidas al enfrentamiento de la violencia entre compañeros íntimos en la adolescencia, bajo la luz de las categorías género y generación. Método: Revisión de alcance realizada en las bases de datos MEDLINE, CINAHL, Scopus y PsycINFO. Se seleccionaron estudios primarios, empíricos, cuantitativos y cualitativos, publicados en tres idiomas. Resultados: De los 3.234 artículos encontrados, 31 compusieron la revisión. La mayoría de las intervenciones se realizaron en el ámbito escolar, con focos de interés en el desarrollo de habilidades para el mantenimiento de relaciones saludables; los tipos de violencia; el conocimiento de alternativas no violentas para la resolución de conflictos; los recursos para ayudar a los involucrados y el rol de los amigos como interventores. Consideraciones finales: Las intervenciones para el enfrentamiento de este fenómeno pueden modificar las relaciones afectivas y sexuales en la adolescencia. Además de la categoría generacional, las acciones deben incorporar la perspectiva de género, relacionada a los procesos de construcción de la feminidad y la masculinidad.

Descriptores: Adolescentes; Violencia entre Compañeros Íntimos; Revisión; Estrategias; Enfermería. 


\section{INTRODUCTION}

Violence is a complex and multifaceted phenomenon. It presents different forms and typologies, highlighting those that are manifested in the context of interpersonal relationships, such as intimate partner violence (IPV). Such violence affects women very much and, therefore, many of them may constitute manifestations of domination relations based on gender iniquities ${ }^{(1)}$.

Studies on IPV usually address the issue in marital relationships among adults ${ }^{(2)}$. However, recently, there are publications aimed at adolescents who, internationally, are known as dating violence ${ }^{(3)}$.

IPV is a worldwide problem, expressing itself as a frequent and transverse phenomenon in diverse cultures, social classes and ethnic groups, both as a victimization and as a perpetration ${ }^{(4)}$. A pioneering study on the subject identified the prevalence of $86.9 \%$ of victimization and $86.8 \%$ of perpetration of some form of IPV among adolescents among 3,200 adolescents investigated in 10 Brazilian states ${ }^{(5)}$.

IPV among adolescents is related to vulnerabilities such as unsafe sex, drug addiction, and suicide attempts. In addition, it may be associated with other childhood and adult violations, both within the family and in the community. Therefore, interventions aimed at prevention are promising ${ }^{(5-6)}$.

A study on IPV prevention programs in adolescence points to the potential of approaches that promote gender equity, since they allow intervention in the construction and maintenance of violent behaviors from childhood ${ }^{(7)}$. Despite this importance, research on IPV coping and prevention interventions is scarce in Latin America, with most publications coming from North American countries ${ }^{(3)}$.

It is necessary to carry out this review, because it is considered necessary to gather data on IPV among adolescents not only to identify their prevalence, risk factors and main types of violence perpetrated ${ }^{(8-9)}$, but to reveal how the information can contribute to the development of interventions that can impact their coping. The purpose of this study is to support the confrontation of the problem based on the proposal of new strategies based on evidence.

\section{OBJECTIVE}

This study aims to map, in the world literature, successful interventions aimed at coping with IPV among adolescents, in the light of the gender and generation categories.

\section{METHOD}

The scope review was developed from the one recommended by Arksey and O'Malley ${ }^{(10)}$ and recommendations made by Levac, Colquhoun and $\mathrm{O}^{\prime}$ Brien $^{(11)}$. The five stages of development of this type of study were followed: (1) identification of the research question; (2) identification of relevant studies; (3) selection of studies; (4) data mapping; (5) collection, summary and reporting of results.

The research question was constructed using the PCC strategy, which advocates as fundamental elements the mnemonic: $\mathbf{P}$ Population; C-Concept and C-Context ${ }^{(12)}$. The following elements were defined: $\mathrm{P}$ (adolescents); C (successful interventions related to intimate partner violence) and C (the community level). From this, the following research question was elaborated: "What are the successful interventions related to intimate partner violence among adolescents in the community?". It should be noted that successful interventions were those that demonstrated that they had achieved the proposed objectives.

After the formulation of the research question, we proceeded to identify the relevant studies in the databases MEDLINE, CINAHL, Scopus and PsycINFO, selected due to their coverage in the international context. The search strategy consisted of three steps: In the first, the search was limited to the MEDLINE and CINAHL databases, followed by an analysis of the most used words in the titles and abstracts of the articles. In the second step, searches were performed on all databases, using the keywords identified in the previous step. In the third step, the list of references of the articles collected was consulted to identify additional studies that had not been mapped in previous steps.

The keywords and terms in English have been synthesized respecting the PCC strategy: P: Adolescent OR Adolescence OR Youth ORTeenagers ORTeen OR Minors. C:Violence OR Courtship OR Dating Violence OR Intimate Partner Violence. C: Prevention \& Control OR Prevention measures OR Intervention studies OR Early intervention.

In each database the search was performed, considering the date of beginning of its publications until 12/31/2017.

For the selection stage of the studies, inclusion criteria were formulated with a view to recovering the greater quantity and quality of available materials. Regarding the population, we included studies that presented successful interventions, related to IPV coping, directed at adolescents under 19 years of age, in agreement with the WHO criteria for definition of adolescents ${ }^{(4)}$. We excluded studies that focused on specific populations, for example, adolescent drug users or street adolescents. Exceptions to this criterion were studies that limited intervention to adolescents who had already had experience of affective or sexual relationship, given the importance of these studies for the purpose of the review.

Regarding the concept, we considered studies that addressed interventions considered successful related to the prevention and coping of IPV among adolescents. Regarding the context, inclusion was from the community level, that is, studies that were conducted in the different areas that work with adolescents, such as Health, Education and Social Assistance, developed by public or private institutions or Non-Governmental Organizations. The use of the term "community scope" is therefore justified for the expansion of interventions and successful experiences aimed at this population group.

We included primary, empirical, quantitative and qualitative studies that addressed successful interventions related to the prevention and coping of IPV among adolescents, published in English, Spanish and Portuguese.

The titles and abstracts selected were read and analyzed by the researcher responsible to identify those eligible for the review. The doubts that arose during this process were discussed among the three reviewers until consensus reached.

Data mapping was done using a form to characterize the production, including title, authors, year, place and period of 
publication, design, objective, method and theoretical framework adopted in the study. In addition, it was considered the focus of interest in each intervention: objectives, results and conclusions, identifying potentialities and limitations. The data were extracted by one reviewer and confirmed by two other reviewers. The differences and doubts were solved in debates until the reach of consensus among all the authors.

The analysis was based on the gender and generation categories. The gender category is based on the difference between the male and female sexes. It consists of an inherent component of social relations and is primordial for the construction of meanings on the relations of power ${ }^{(13)}$. The generation category establishes the space occupied by the different generational categories, which suffer the impact of the events of the society that surround them and determine them. More than age, generation defines the social statutes of a given social group by the political and ideological similarities that differentiate them from others, in time and space ${ }^{(14)}$.

\section{RESULTS}

Initially, 3,234 articles were found. From the review of titles, 2,968 articles were excluded and 266 papers were kept for analysis of abstracts. From these, 95 were repeated. In the next step, 67 articles were selected for full reading, in order to detect the pertinent ones to answer the research question. We excluded studies that did not meet the inclusion criteria and those that were not found. Finally, 31 articles were selected to compose the review. The description of the searches and the selection of articles was based on the Preferred Reporting Items for Systematic Review and Meta-Analyzes ${ }^{(15)}$ (Figure 1). Chart 1 shows the selected publications.

Most of the studies were published in the United States $(n=22)$, followed by Spain ( $n=2)$ and Mexico $(n=2)$. Canada, Switzerland, Haiti and the Caribbean produced one study each and another was conducted by a partnership between Canada and United Kingdom. The language of production was mostly English ( $n=28$ articles). Three articles were written in Spanish.

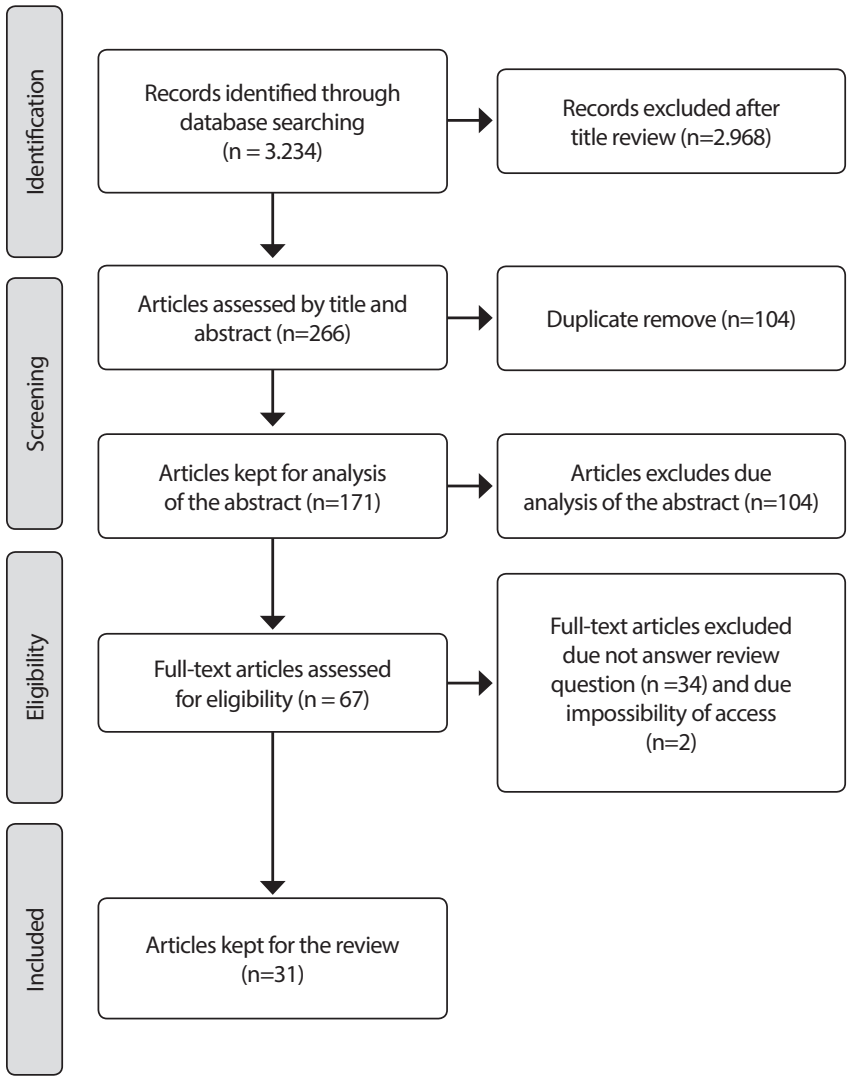

Figure 1- Flow diagram of selection of review articles, according to PRISMA, Sao Paulo State, Brazil, 2018

The articles were published between 1995 and 2017. The years of greatest concentration of publications were $2015(n=5)$ and 2013 ( $n=4)$, followed by 2017, 2016 and 2012, with three publications each year. In 2014, 2009 and 1997 two studies were published each year. In 2010, 2008, 2006, 2005, 2004, 1998 and 1995 one article was published per year.

Chart 1- Selected articles in the scope review on successful interventions aimed at coping with intimate partner violence among adolescents, São Paulo State, Brazil, 2018

\begin{tabular}{|c|c|c|c|c|}
\hline AUTHORS & TITLE & $\begin{array}{l}\text { ORIGIN } \\
\text { COUNTRY }\end{array}$ & JOURNAL & YEAR \\
\hline $\begin{array}{l}\text { Sargent KS, Jouriles EN, Rosenfield D, } \\
\text { McDonald R } \mathrm{R}^{(16)}\end{array}$ & $\begin{array}{l}\text { A High School-based evaluation of TakeCARE, a video Bystander } \\
\text { Program to Prevent Adolescent Relationship Violence }\end{array}$ & USA & $\begin{array}{l}\text { Journal Youth } \\
\text { Adolescence }\end{array}$ & 2017 \\
\hline $\begin{array}{l}\text { Sosa-Rubi SG, Saavedra-Avendano B, } \\
\text { Piras C, Buren SJV, } \\
\text { Bautista-Arredondo } \mathrm{S}^{(17)}\end{array}$ & $\begin{array}{l}\text { True love: effectiveness of a school-based program to reduce } \\
\text { dating violence among adolescents in mexico city }\end{array}$ & Mexico & Prevention Science & 2017 \\
\hline $\begin{array}{l}\text { Raible CA, Dick R, Gilkerson F, Mattern } \\
\text { CS, James L, Miller } E^{(18)}\end{array}$ & $\begin{array}{l}\text { School Nurse-delivered adolescent relationships abuse } \\
\text { prevention }\end{array}$ & USA & $\begin{array}{l}\text { Journal of School } \\
\text { Health }\end{array}$ & 2017 \\
\hline $\begin{array}{l}\text { Joppa MC, Rizzo CJ, Nieves AV, Brown } \\
\text { LK }^{(19)}\end{array}$ & $\begin{array}{l}\text { Pilot investigation of the Katie Brown Educational Program: a } \\
\text { school-community partnership }\end{array}$ & USA & $\begin{array}{l}\text { Journal of School } \\
\text { Health }\end{array}$ & 2016 \\
\hline $\begin{array}{l}\text { Levesque DA, Johnson JL, Welch CA, } \\
\text { Prochaska JM, Paiva AL }{ }^{(20)}\end{array}$ & $\begin{array}{l}\text { Teen dating violence prevention: cluster-randomized trial of } \\
\text { Teen Choices, an online, stage-based program for healthy, } \\
\text { nonviolent relationships }\end{array}$ & USA & $\begin{array}{l}\text { Psychology of } \\
\text { Violence }\end{array}$ & 2016 \\
\hline Gage AJ, Honoré JG, Deleon J (21) & $\begin{array}{l}\text { Short-term effects of a violence prevention curriculum on } \\
\text { knowledge of dating Violence among high school students in } \\
\text { Port-au-Prince, Haiti }\end{array}$ & Haiti & $\begin{array}{l}\text { Journal of } \\
\text { Communication in } \\
\text { Healthcare }\end{array}$ & 2016 \\
\hline
\end{tabular}




\begin{tabular}{|c|c|c|c|c|}
\hline AUTHORS & TITLE & $\begin{array}{l}\text { ORIGIN } \\
\text { COUNTRY }\end{array}$ & JOURNAL & YEAR \\
\hline $\begin{array}{l}\text { Miller S, Williams J, Cutbush S, Gibbs D, } \\
\text { Clinton-Sherrod M, Jones } \mathrm{S}^{(22)}\end{array}$ & $\begin{array}{l}\text { Evaluation of the Start Strong initiative: preventing teen } \\
\text { dating violence and promoting healthy relationships among } \\
\text { middle school students. }\end{array}$ & USA & $\begin{array}{l}\text { Journal of } \\
\text { Adolescent Health }\end{array}$ & 2015 \\
\hline $\begin{array}{l}\text { Taylor BG, Mumford EA, } \\
\text { Stein ND }\end{array}$ & $\begin{array}{l}\text { Effectiveness of "Shifting Boundaries" teen dating violence } \\
\text { prevention program for subgroups of middle school students }\end{array}$ & USA & $\begin{array}{l}\text { Journal of } \\
\text { Adolescent Health }\end{array}$ & 2015 \\
\hline $\begin{array}{l}\text { Williams J, Miller S, Cutbush S, Gibbs } \\
\text { D, Clinton-Sherrod M, Jones } S^{(24)}\end{array}$ & $\begin{array}{l}\text { A latent transition model of the effects of a teen dating } \\
\text { violence prevention initiative }\end{array}$ & USA & $\begin{array}{l}\text { Journal of } \\
\text { Adolescent Health }\end{array}$ & 2015 \\
\hline $\begin{array}{l}\text { McLeod DA, Jones R, } \\
\text { Cramer } \mathrm{EP}^{(25)}\end{array}$ & $\begin{array}{l}\text { An evaluation of a school-based, peer-facilitated, healthy } \\
\text { relationship program for at-risk adolescents }\end{array}$ & USA & Children \& School & 2015 \\
\hline $\begin{array}{l}\text { Miller E, Goldstein S, McCauley HL, } \\
\text { Jones KA, Dick R, Jetton J, Silverman } \\
\text { JG, Blackburn S, Monasterio E, James } \\
\text { L, Tancredi DJ }\end{array}$ & $\begin{array}{l}\text { A school health center intervention for abusive adolescent } \\
\text { relationships: a cluster RCT }\end{array}$ & USA & Pediatrics & 2015 \\
\hline $\begin{array}{l}\text { Alexander CM, Hutchinson AN, } \\
\text { Clougher KM, Davis HA, Shepler DK, } \\
\text { Ambroise } \mathrm{Y}^{(27)}\end{array}$ & $\begin{array}{l}\text { Adolescent dating violence: application of a U.S. primary } \\
\text { prevention program in St. Lucia }\end{array}$ & Caribbean & $\begin{array}{l}\text { Journal of } \\
\text { Counseling \& } \\
\text { Development }\end{array}$ & 2014 \\
\hline $\begin{array}{l}\text { Peskin MF, Markham CM, Shegog R, } \\
\text { Baumler ER, Addy RC, Tortolero SR }{ }^{(28)}\end{array}$ & $\begin{array}{l}\text { Effects of the It囚s Your Game ... Keep It Real program on } \\
\text { dating violence in ethnic-minority middle school youths: a } \\
\text { group randomized trial }\end{array}$ & USA & $\begin{array}{l}\text { Research and } \\
\text { Practice }\end{array}$ & 2014 \\
\hline $\begin{array}{l}\text { Belknap RA, Haglund K, Felzer H, } \\
\text { Pruszynski J, Schneider J(29) }\end{array}$ & $\begin{array}{l}\text { A theater intervention to prevent teen dating violence for } \\
\text { Mexican-American middle school students }\end{array}$ & USA & $\begin{array}{l}\text { Journal of } \\
\text { Adolescent Health }\end{array}$ & 2013 \\
\hline $\begin{array}{l}\text { Taylor BG, Stein ND, Mumford EA, } \\
\text { Woods D }\end{array}$ & $\begin{array}{l}\text { Shifting Boundaries: an experimental evaluation of a dating } \\
\text { violence prevention program in middle schools }\end{array}$ & USA & Prevention Science & 2013 \\
\hline $\begin{array}{l}\text { Oscós-Sanchez MA, Lesser J, Oscós- } \\
\text { Flores LD(31) }\end{array}$ & $\begin{array}{l}\text { High school students in a health career promotion program } \\
\text { report fewer acts of aggression and violence }\end{array}$ & USA & $\begin{array}{l}\text { Journal of } \\
\text { Adolescent Health }\end{array}$ & 2013 \\
\hline $\begin{array}{l}\text { Maya BM, Ortega-Rivera FJ, Jiménez } \\
\text { VS }^{(32)}\end{array}$ & $\begin{array}{l}\text { El DaViPoP: un programa de prevención de violencia en el cortejo } \\
\text { y las parejas adolescentes }\end{array}$ & Spain & $\begin{array}{l}\text { Apuentes de } \\
\text { Psicologia }\end{array}$ & 2013 \\
\hline $\begin{array}{l}\text { Foshee VA, Reyes HLM, Ennett ST, } \\
\text { Jessica DC, Bauman KE, Bowling } \mathrm{M}^{(33)}\end{array}$ & $\begin{array}{l}\text { Assessing the effects of Families for Safe Dates, a family-based } \\
\text { teen dating abuse prevention program }\end{array}$ & USA & $\begin{array}{l}\text { Journal of } \\
\text { Adolescent Health }\end{array}$ & 2012 \\
\hline $\begin{array}{l}\text { Enriquez M, Kellu PJ, Cheng AL, } \\
\text { Hunter J(34) }\end{array}$ & $\begin{array}{l}\text { An intervention to address interpersonal violence among low- } \\
\text { income Midwestern Hispanic-American teens }\end{array}$ & USA & $\begin{array}{l}\text { Journal of } \\
\text { Immigrant and } \\
\text { Minority Health }\end{array}$ & 2012 \\
\hline Hamby S, Puy J, Monnier S(35) & $\begin{array}{l}\text { Adapting dating violence prevention to francophone } \\
\text { Switzerland: a story of intra-western cultural differences }\end{array}$ & Switzerland & $\begin{array}{l}\text { Violence and } \\
\text { Victims }\end{array}$ & 2012 \\
\hline $\begin{array}{l}\text { Pick S, Leenen I, Givaudan M, Prado } \\
\mathrm{A}^{(36)}\end{array}$ & $\begin{array}{l}\text { Yo quiero, yo puedo...prevenir la violência: programa breve de } \\
\text { sensibilización sobre violencia en el noviazgo }\end{array}$ & Mexico & Salud Mental & 2010 \\
\hline $\begin{array}{l}\text { Wolfe DA, Crooks C, Chiodo D, Hughes } \\
\text { R, Ellis W, Stitt L, } \\
\text { Donner A }\end{array}$ & $\begin{array}{l}\text { A school-based program to prevent adolescent dating } \\
\text { violence: a cluster randomized trial }\end{array}$ & $\begin{array}{l}\text { Canada } \\
\text { and United } \\
\text { Kingdom }\end{array}$ & JAMA Pediatrics & 2009 \\
\hline Garrido V, Casas $\mathrm{M}^{(38)}$ & $\begin{array}{l}\text { La prevención de la violencia en la relación amorosa entre } \\
\text { adolescentes a través del taller «La Máscara del Amor» }\end{array}$ & Spain & $\begin{array}{l}\text { Revista de } \\
\text { Educación }\end{array}$ & 2009 \\
\hline $\begin{array}{l}\text { Moskovic CS, Guiton G, Chirra A, } \\
\text { Núñez AE, Bigby J, Stahl C, Robertson } \\
\text { C, Thul EC, Miller E, Sims A, Sachs CJ, } \\
\text { Pregler JP(39) }\end{array}$ & $\begin{array}{l}\text { Impact of participation in a community-based intimate } \\
\text { partner violence prevention program on medical students: a } \\
\text { multi-center study }\end{array}$ & USA & $\begin{array}{l}\text { Journal of General } \\
\text { Internal Medicine }\end{array}$ & 2008 \\
\hline $\begin{array}{l}\text { Jaycox LH, McCaffrey D, } \\
\text { Eiseman B, Aronoff J, Shelley GA, } \\
\text { Collins RL, Marshall GN(40) }\end{array}$ & $\begin{array}{l}\text { Impact of a school-based dating violence prevention program } \\
\text { among Latino teens: randomized controlled effectiveness trial }\end{array}$ & USA & $\begin{array}{l}\text { Journal of } \\
\text { Adolescent Health }\end{array}$ & 2006 \\
\hline $\begin{array}{l}\text { Foshee VA, Bauman KE, } \\
\text { Ennett ST, Suchindran C, Benefield T, } \\
\text { Linder F } \text { Fil) }^{(4)}\end{array}$ & $\begin{array}{l}\text { Assessing the effects of the dating violence prevention } \\
\text { program "Safe Dates" using random coefficient regression } \\
\text { modeling }\end{array}$ & USA & Prevention Science & 2005 \\
\hline
\end{tabular}




\begin{tabular}{|c|c|c|c|c|}
\hline AUTHORS & TITLE & $\begin{array}{l}\text { ORIGIN } \\
\text { COUNTRY }\end{array}$ & JOURNAL & YEAR \\
\hline $\begin{array}{l}\text { Foshe VA, Bauman KE, Ennett ST, } \\
\text { Linder F, Benefield T, } \\
\text { Suchindran C(42) }\end{array}$ & $\begin{array}{l}\text { Assessing the long-term effects of the Safe Dates program } \\
\text { and a booster in preventing and reducing adolescent dating } \\
\text { violence victimization and perpetration }\end{array}$ & USA & $\begin{array}{l}\text { Research and } \\
\text { Practice }\end{array}$ & 2004 \\
\hline $\begin{array}{l}\text { Foshee VA, Bauman KE, } \\
\text { Arriaga XB, Helms RW, Koch GG, } \\
\text { Linder GF( }{ }^{(43)}\end{array}$ & $\begin{array}{l}\text { An evaluation of Safe Dates, an adolescent dating violence } \\
\text { prevention program }\end{array}$ & USA & $\begin{array}{l}\text { American Journal } \\
\text { of Public Health }\end{array}$ & 1998 \\
\hline $\begin{array}{l}\text { Avery-leaf S, Cascardi M, O'Leary, } \\
\text { Cano A }{ }^{(44)}\end{array}$ & $\begin{array}{l}\text { Efficacy of a dating violence prevention program on attitudes } \\
\text { justifying aggression }\end{array}$ & USA & $\begin{array}{l}\text { Journal of } \\
\text { Adolescent Health }\end{array}$ & 1997 \\
\hline Macgowan $\mathrm{MJ}^{(45)}$ & $\begin{array}{l}\text { An evaluation of dating violence prevention program for } \\
\text { middle school students }\end{array}$ & USA & $\begin{array}{l}\text { Violence and } \\
\text { Victms }\end{array}$ & 1997 \\
\hline Lavoie F, Vézina L, Piché C, Boivin $\mathrm{M}^{(46)}$ & $\begin{array}{l}\text { Evaluation of a prevention program for violence in teen dating } \\
\text { relationships }\end{array}$ & Canada & $\begin{array}{l}\text { Journal of } \\
\text { interpersonal } \\
\text { violence }\end{array}$ & 1995 \\
\hline
\end{tabular}

Eighteen articles were selected in the MEDLINE database, six in Scopus, five in PsycINFO and two in CINAHL. Considering the area of study concentration, 26 were produced by Health Sciences. 17 specified the area of belonging as: Psychology $(n=6)$, Mental Health $(n=3)$, Public Health; Pediatrics $(n=1)$; Medicine $(n=1)$, Women's Health $(n=1)$, Nursing $(n=1)$ and one in partnership between Nursing and Arts $(n=1)$. Four studies belonged to the Sciences of Education and another to Social Assistance.

Regarding the methodological design, 27 articles were quantitative, two were qualitative and two were mixed methods. Further information regarding the design of the studies are described in Table 1.

Table 1 - Distribution of publications regarding methodology, São Paulo State, Brazil, 2018

\begin{tabular}{lcc}
\multicolumn{1}{c}{ Methodology } & n & $\%$ \\
\hline Qualitative & 2 & 6.45 \\
$\quad$ Content analysis & 2 & 6.45 \\
Quantitative & 27 & 87.10 \\
$\quad$ Experimental & 17 & 54.84 \\
Quasi-experimental with control group & 8 & 25.81 \\
Cohort & 2 & 6.45 \\
Mix-methods & 2 & 6.45 \\
$\quad$ Quasi-experimental + content analysis & 2 & 6.45 \\
Total & 31 & 100 \\
\hline
\end{tabular}

Data analysis of the quantitative studies was carried out using statistical models, which measured the variables before and after the intervention. In the qualitative studies, the technique of content analysis was used.

The theoretical frameworks used were: Social Cognitive Theory $(n=3)$, Social Learning Theory $(n=3)$, Positive Childhood Development $(n=1)$, Theater of the Oppressed $(n=1)$, SocioEcological Approach $(n=1)$, Grounded Theory $(n=1)$, Gender Violence $(n=1)$, Socio-Affective Theory $(n=1)$ and Transtheorical Model $(n=1)$. Eighteen studies did not explain the theoretical framework adopted.
The studies presented successful interventions or their follow-up, aimed at primary and secondary prevention, and at coping with IPV among adolescents at the community level. Most of the interventions were implemented in the school context (27 interventions), two of which were started in school and completed in the community and virtual settings. The others were performed in the domestic space $(n=1)$ and in a community center for young people $(n=1)$.

Interventions implemented in the school context $(n=29)$ related to the development of 23 IPV among adolescents prevention programs. Two studies ${ }^{(22,24)}$ evaluated the Star Strong: Building Healthy Teen Relationships Initiative curriculum in the short and long term, respectively. Two other studies ${ }^{(23,30)}$ analyzed the Shifting Boundaries program, with interventions in the classroom and at school.

The Safe Dates program was identified in five articles related to the follow-up of the initial version of the intervention ${ }^{(43)}$; late monitoring ${ }^{(41-42)}$; and adaptations of the original version of the intervention ${ }^{(21,35)}$, one of which dealt with cross-cultural adaptation.

Interventions associated with the school context related to the introduction of curricular models in disciplines, especially Health Education or Physical Education. The actions were of short or long duration, ranging from five to 24 sessions. Two interventions in school health services highlighted the School Health Center Healthy Adolescent Relationships ${ }^{(26)}$ and Project Conect $^{(18)}$ programs, which aimed at orientations about IPV among adolescents in clinical encounters. The second program was developed by nurses in five urban and rural schools.

It was also observed that the interventions that dealt with some form of curricular implementation of the subject related to IPV among adolescents presented convergent themes (Chart 2).

Regarding the gender category, four interventions stimulated changes in attitudes that reiterated gender inequalities in relationships among adolescents ${ }^{(17,32,34,44)}$, based on information on the determination of IPV among adolescents based on stereotypes attributed to the female and the male. The intervention DaVIPoP ${ }^{(32)}$ was highlighted, during an optional gender discipline. The authors commented that this aspect may have favored the results of the intervention. The generation category was not addressed in any of the articles that composed this review. 
Chart 2 - Focus of studies on interventions related to intimate partner violence among adolescents (curricular implementation), São Paulo State, 2018

\begin{tabular}{|c|c|}
\hline Focus of interest & Studies \\
\hline Developing ability to maintain healthy relationships & 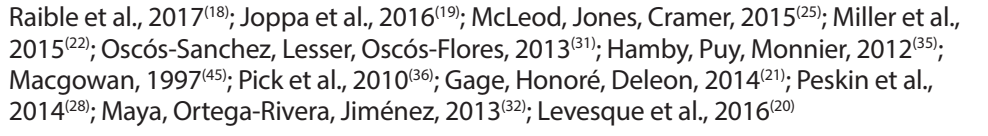 \\
\hline $\begin{array}{l}\text { Types of violence perpetrated by intimate partners and } \\
\text { how to recognize each form }\end{array}$ & 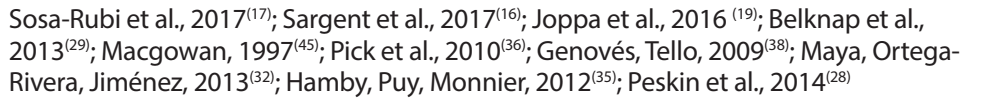 \\
\hline $\begin{array}{l}\text { Knowledge of non-violent alternatives for conflict resolution } \\
\text { in affective or sexual relationships }\end{array}$ & $\begin{array}{l}\text { Avery-leaf et al, } 1997^{(43)} \text { Macgowan, } 1997^{(45)} \text {; Pick et al., 2010 } \\
\text { 2014(21); Levesque et al., } 2016^{(20)}\end{array}$ \\
\hline $\begin{array}{l}\text { Knowledge about resources and institutions that can } \\
\text { provide help to the adolescent in situations of IPV }\end{array}$ & 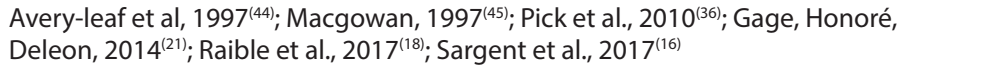 \\
\hline $\begin{array}{l}\text { Role of friends as respondents in IPV among adolescents } \\
\text { situation }\end{array}$ & $\begin{array}{l}\text { Taylor, Mumford, Stein, 2015(23); Foshee et al., 1998 } \\
\text { Gage, Honoré, Deleon, 2014(21); Sargent et al., } 2017^{(16)}\end{array}$ \\
\hline
\end{tabular}

Note: In some cases, in the same intervention, more than one focus of interest was recorded; IVP: intimate partner violence

Two studies were conducted with health professionals. The first reported the impact generated on medical students, educators in an IPV among adolescents prevention program. Besides the curricular intervention, there was an improvement in the participants' confidence to face the problem ${ }^{(39)}$. The second described the implementation and evaluation of an intervention on IPV among adolescents in nursing offices in schools. The nurses who participated in the study report having raised the frequency with which they addressed the problem of IPV among adolescents in nursing consultations and the adolescents demonstrated an increase in knowledge about IPV and the capacity to help friends in situations of violence ${ }^{(18)}$.

Two interventions took place in community centers for young Swiss, named Sortir Ensemble et Se Respecter ${ }^{(35)}$. They were implemented through 19 focus groups with discussions about the values of love relationships, the recognition of abusive relationships and the maintenance of respect in the relationship. The other intervention was Families for Safe Dates ${ }^{(33)}$, developed in the domestic environment and directed to parents or responsible for adolescents. It sought to provide a propitious family space for discussions related to IPV among adolescents.

The strategies adopted in the interventions were divided into two groups. The first one consisted of studies that used traditional teaching-learning methodology ${ }^{(14)}$, based on the transmission of unidirectional knowledge and on the passivity of adolesce $n^{(18-19,21,23-24,30,32,39-42,44-45)}$. The second group was composed of interventions, using innovative strategies close to the active teaching-learning methodology, which considers the construction of knowledge from the social insertion of the adolescent. In this perspective, the use of games, videos, vignettes, storytelling, music analysis, theater, case studies, workshops and visual interventio $\mathrm{ns}^{(16-17,20,22,25,27-29,31,35-38,43,46)}$. In some studies, the intervention used one or more strategies, concomitantly.

The review also made it possible to identify the performance of health professionals and other areas in interventions. The teachers were appointed as the responsible for 12 interventions, and in five they received training lasting from four to 20 hours. The studies also identified as responsible for these facilitated interventions not linked to schools ${ }^{(6)}$, undergraduate students of Theater and Medicine $(n=2)$, researchers $(n=5)$, community professionals $(n=2)$, health professionals $(n=2)$, health educators $(n=1)$ and lawyers $(n=1)$. In one study, it was not possible to identify the professional responsible and in two studies the activity was coordinated by other adolescents trained to work with peers.

\section{DISCUSSION}

The scope review allowed knowing the interventions considered successful with respect to the prevention and the confrontation of IPV among adolescents, the methods used, the places of implementation, the professionals responsible and the limitations of the studies.

The mapping points to the non-representativeness of Brazilian studies related to the theme. This aspect may be associated with the lack of interventions or the lack of registration and dissemination of initiatives carried out with adolescents in periodicals with a high impact factor. A similar result was identified by an integrative review that mapped studies of IPV among adolescents prevention in the Health area $^{(3)}$.

The setting that concentrates the greatest number of interventions is school. This result reiterates the school as a privileged space for the formation and social participation of adolescents. It was found that the interventions in the schools were also related to the Health sector, developed mainly in the subjects related to the subject, such as Health Education and Physical Education. Therefore, it is understood that the focus of violence still focuses on the biological and psychological dimensions of adolescence.

This reality can be evidenced in a study undertaken by Carlos et al. ${ }^{(47)}$, which identified that interventions related to affective and sexual relationships carried out in the school environment are usually centered on training aimed at reducing behaviors characterized as risk among adolescents.

The link between school institutions and other services that make up the IPV among adolescents coping network, such as Health, was not portrayed in the studies that made up the review. The health professionals are far from the interventions considered 
successful, directed to the prevention and the confrontation of the IPV among adolescents, due to its absence in the settings and in the coordination of the implemented actions. This difficulty in defining roles and responsibilities in the planning and execution of intersectoral interventions, especially between school and health, was identified in another study ${ }^{(48)}$.

Several studies have converged to the understanding that providing adolescents with information about IPV represents a crucial strategy for preventing and coping with this problem $^{(16-19,21,28-29,32,35-36,38,44-45)}$. For that, they used both traditional and innovative teaching-learning methodologies. The latter were more appropriate for goal achievement and for attracting adolescents $^{(35)}$.

The conduction and evaluation of the interventions were mostly associated with positivism, with prevalence of the quantitative methodology. However, given the complexity of the IPV among adolescents, it is essential that the analyzes be deepened, considering its historical and social determination, underlying historical and dialectical materialism ${ }^{(49)}$. In this framework, qualitative approaches can be more powerful to reveal the different faces of the problem.

The studies do not reveal how the impacts of interventions behave over time. Only four interventions ${ }^{(20,24,37,41)}$ were followed for periods ranging from six months to three and a half years. Foshee et al. ${ }^{(42)}$ verified that a booster after three and a half years of the first intervention was not sufficient to contain the progression of cases of IPV among adolescents among participants.

The results of the review showed that it is fundamental that the interventions are not restricted to the transmission of concepts and information regarding IPV among adolescents, so as to enable a critical understanding of the affective and sexual relationships in adolescence. By using the generation category, it can be understood that interventions that do not consider the adolescent as a fundamental part of the IPV coping process can distance this subject from the services that implement it and can create a barrier of silence between adolescents and professionals ${ }^{(50)}$.

One study ${ }^{(31)}$ differed from the others when presenting a critique of the mere transmission of information about IPV as a way of intervening in the phenomenon. It suggests encouraging positive life choices to achieve better results in coping with IPV among adolescents and considers that adolescent living may be more promising than content transmission. Another study ${ }^{(34)}$ presented the use of activities that involved the collaborative participation of adolescents as a strategy for a successful intervention.

Such strategies are capable of focusing on issues resulting from intergenerational relations, which, historically, make it difficult to identify and cope with the problem ${ }^{(18,28-29,37,40)}$. This aspect can be expressed through the invisibility of adolescents in services and the barriers to establishing linkage and dialogue between them and professionals.

In view of the results, the question is: To what extent do pointbased interventions, guided by the positivist perspective and centered on the unidirectional conception of the transmission of knowledge, produce transformations of reality and overcoming the problem? As a starting point for this question, it is mentioned that there are scientific records of interventions for the prevention of IPV among adolescents, considered successful since the beginning of the 1990s. However, it is perceived that these initiatives did little to change the reality, since the problematic of IPV leads to more and more harm among adolescents.

Some investigations ${ }^{(17,32,34,44)}$ have pointed out the need to consider issues related to the gender category for the development of IPV among adolescents prevention and coping programs. Although the first study indicating this need was carried out almost two decades ago, it was found that the current.

It is understood that using the concept of gender in the interventions can contribute to the confrontation of the problematic of IPV among adolescents, since it allows to identify sexist patterns established by the social construction of men and women, in which the feminine gender is subalternized ${ }^{(1)}$. From this identification, it is possible to promote reflections about violent behaviors naturalized in society, which trigger the experience of violent relationships, causing physical and psychological damages to the victims.

This conclusion corroborates the results of a study ${ }^{(22)}$ that evaluated an intervention aimed at coping with IPV among adolescents and identified that the emphasis on actions that promote the deconstruction of gender stereotypes may imply a decrease in IPV in future relationships.

Most studies do not discuss results from a gender perspective. It is noticed that, normally, when this discussion is intended, it happens considering the differences between the biological sexes. However, other studies ${ }^{(28,35,37,45)}$ have indicated the need for discussion from the gender perspective, given the implications based on gender stereotypes and social roles attributed to boys and girls.

The gender approach is indispensable for conducting interventions and for reflecting the results found in the studies. The need to deepen and broaden the discussion from the social categories is materialized with the purpose of proposing new strategies of intervention with a view to overcoming the naturalization of the IPV among adolescents, starting from the construction of an equitable society between gender and generations.

The interventions analyzed converged to the need for qualification of the coordinators of the interventions, usually teachers. However, this topic was not discussed in depth in the articles. Nor were evaluations of these interventions carried out, with the exception of one study that presented it superficially ${ }^{(38)}$. This indicates a fragility regarding the training and the periodic evaluation of the professionals who participate in the process of coping with IPV among adolescents.

Qualification based on traditional education, which does not allow the construction and collective reflection of content, can limit the possibility of success of the intervention, since it does not allow the professional to participate in the process in a critical and reflective way ${ }^{(1)}$.

The findings of this review can be used to guide the construction of proposals for coping with IPV among adolescents by identifying important themes to compose an intervention and finding unworked subjects, but considered necessary by the studies for the success of a intervention. In addition, considering that the interventions analyzed were, mainly, a quantitative and positivist approach, we identify the need for qualitative studies on the subject. 
From this, it is possible to combine what was evidenced as a successful intervention to confront the IPV among adolescents to a qualitative, critical and emancipatory perspective, directing efforts and resources (institutional, political, financial and media) for interventions that promote the participation of adolescents in the process of construction, execution and evaluation of an intervention strategy.

\section{Study limitations}

This study had as limitations the fact that only one reviewer had analyzed the titles and abstracts selected, being discussed among three reviewers the cases of doubts and the impossibility of access to two studies selected in the searches.

\section{Contributions to the sector of Nursing}

Regarding the implications for the Nursing area, there is a need for interventions for the prevention and coping of IPV among adolescents in the setting of health institutions, through individual and collective assistance to adolescents, as well as the development of partnerships with institutions from other areas. In addition, it is important to highlight the importance of studies aimed at knowing and analyzing the professional practices carried out on the subject, with the purpose of identifying and disseminating successful interventions and subsidizing overcoming the problem.

\section{FINAL CONSIDERATIONS}

The scope review mapped interventions for prevention and coping with IPV among adolescents worldwide. The study showed an important contradiction: although the first interventions recorded in the literature date back to the 1990s and since then many others have been developed, the objective reality reveals the expansion of violent affective and/or sexual relationships sustained by iniquities of gender among adolescents.

One hypothesis to be raised is that these interventions, for the most part, transmit information about the problem, without allowing the active protagonism of the adolescents themselves in the intervention actions, aiming at transforming and overcoming the problem. The interventions that composed this review were considered successful by their authors, which indicate that the goal of information transmission was achieved. However, disclosure alone appears to be insufficient for the prevention and coping of a phenomenon as complex as the IPV among adolescents.

Community interventions aimed only at adolescents end up presenting themselves as a limitation for the prevention and coping of IPV situations. It is agreed that IPV among adolescents will be revealed as a possibility for confrontation as adolescents are able to recognize and problematize violence. However, it is necessary not only to inform them about this problem, but also to provide spaces for listening and dialogue, respecting their positions and experiences.

In addition, there is a need to build and implement intersectoral interventions involving families and social groups to which adolescents belong. In this context, it is also fundamental to create and implement public policies that are transversal to the areas that participate in promoting the quality of life of adolescents, such as Health, Education, Social Assistance and Justice.

\section{FUNDING}

This work was carried out with the support of the Coordination of Improvement of Higher Education Personnel - Brazil (CAPES - Coordenação de Aperfeiçoamento de Pessoal de Nível Superior) - Financing Code 001.

\section{REFERENCES}

1. Fonseca RMGS, Oliveira RNG, Fornari LF. Prática educativa em direitos sexuais e reprodutivos: a oficina de trabalho crítico-emancipatória de gênero. In: Kalinowski C, Crozeta K, Costa M (Orgs.). PROENF Programa de Atualização em Enfermagem: Atenção Primária e Saúde da Família: Ciclo 6. Porto Alegre: Artmed Panamericana; 2017. p. 59-119.

2. Jennings WG, Okeem C, Piquero AR, Sellers CS, Theobald D, Farrington DP. Dating and intimate partner violence among young persons ages 15-30: evidence from a systematic review. Aggress Violent Behav [Internet]. 2017 [cited 2018 Oct 31];33:107-25. Available from: doi:10.1016/j.avb.2017.01.007

3. Oliveira RNG, Gessner R, Brancaglioni BCA, Fonseca RMGS, Egry EY. Preventing violence by intimate partners in adolescence: an integrative review. Rev Esc Enferm USP [Internet]. 2016 [cited 2018 Jul 2];50(1):134-43. Available from: http://dx.doi.org/10.1590/ S0080-623420160000100018

4. World Health Organization, London School of Hygiene and Tropical Medicine. Preventing intimate partner and sexual violence against women: taking action and generating evidence [Internet]. Geneva:WHO; 2012. 94 p. Available from: http://www.who.int/violence_injury_ prevention/publications/violence/9789241564007_eng.pdf

5. Cecchetto F, Oliveira QBM, Njaine K, Minayo MC de S. Violências percebidas por homens adolescentes na interação afetivo-sexual em dez cidades brasileiras. Interface (Botucatu) [Internet]. 2016 [cited 2018 Nov 01];20(59):853-64. Available from: http://dx.doi. org/10.1590/1807-57622015.0082

6. Minayo M, Assis S, Njaine K. Amor e violência: um paradoxo das relações de namoro e do "ficar" entre jovens brasileiros. Rio de Janeiro: FIOCRUZ; 2011. 238 p.

7. Foshee VA, Karriker-Jaffe KJ, Reyes HLM, Ennett ST, Suchindran C, Bauman KE, et al. What accounts for demographic differences in trajectories of adolescent dating violence? An examination of intrapersonal and contextual mediators. J Adolesc Health [Internet]. 2008 [cited 2018 Jul 2];42(6):596-604. Available from: doi: 10.1016/j.jadohealth.2007.11.005 
8. Lewis SF, Fremouw W. Dating violence: a critical review of the literature. Clin Psychol Rev [Internet]. 2001 [cited 2018 Jul 2];21(1):105-27. Available from: http://www.ncbi.nlm.nih.gov/pubmed/11148892

9. Leen E, Sorbring E, Mawer M, Holdsworth E, Helsing B, Bowen E. Prevalence, dynamic risk factors and the efficacy of primary interventions for adolescent dating violence: An international review. Aggress Violent Behav [Internet]. 2013 [cited 2018 Jul 2];18(1):159-74. Available from: https://doi.org/10.1016/j.avb.2012.11.015

10. Arksey H, O'Malley L. Scoping studies: Towards a methodological framework. Int J Soc Res Methodol Theory Pract [Internet]. 2005 [cited 2018 Nov 01];8(1):19-32. Available from: doi: 10.1080/1364557032000119616

11. Levac D, Colquhoun H, O'Brien KK. Scoping studies: advancing the methodology. Implement Sci [Internet]. 2010 [cited 2018 Jul 2];5:69. Available from: https://doi.org/10.1186/1748-5908-5-69

12. Joanna Briggs Institute Reviewers' Manual 2015: Methodology for JBI Scoping Reviews. The Joanna Briggs Institute, Austrália, 2015.

13. Scott J. Gênero: uma categoria útil de análise histórica. Educ Real [Internet]. 1995 [cited 2018 Nov 01\};20(2):71-99. Available from: https:// edisciplinas.usp.br/pluginfile.php/185058/mod_resource/content/2/G\%C3\%AAnero-Joan\%20Scott.pdf

14. Egry EY, Fonseca RMGS, Oliveira MAC. [Science, public health and nursing: highlighting the gender and generation categories in the episteme of práxis]. Rev Bras Enferm [Internet]. 2013 [cited 2018 Jul 2];66(esp):119-33. Available from: http://dx.doi.org/10.1590/S003471672013000700016. Portuguese.

15. Liberati A, Altman DG, Tetzlaff J, Mulrow C, Gøtzsche PC, loannidis JPA, et al. The PRISMA statement for reporting systematic reviews and meta-analyses of studies that evaluate healthcare interventions: explanation and elaboration. BMJ. 2009;339:b2700. doi: 10.1136/bmj. b2700

16. Sargent KS, Jouriles EN, Rosenfield D, McDonald R. A high school-based evaluation of TakeCARE, a video bystander program to prevent adolescent relationship violence. J Youth Adolesc. 2017 ;46(3):633-43. doi: 10.1007/s10964-016-0622-z

17. Sosa-Rubi SG, Saavedra-Avendano B, Piras C, Van Buren SJ, Bautista-Arredondo S. True love: effectiveness of a school-based program to Reduce dating violence among adolescents in mexico city. Prev Sci [Internet]. 2017 [cited 2018 Jul 2];18(7):804-17. Available from: https:// doi.org/10.1007/s11121-016-0718-4

18. Raible CA, Dick R, Gilkerson F, Mattern CS, James L, Miller E. School nurse-delivered adolescent relationship abuse prevention. J Sch Health. 2017;87(7):524-30. doi: 10.1111/josh.12520

19. Joppa MC, Rizzo CJ, Nieves A V., Brown LK. Pilot investigation of the katie brown educational program: a school-community partnership. J Sch Health. 2016;86(4):288-97. doi: 10.1111/josh.12378

20. Levesque DA, Johnson JL, Welch CA, Prochaska JM, Paiva AL. Teen dating violence prevention: cluster-randomized trial of teen choices, an online, stage-based program for healthy, nonviolent relationships. Psychol Violence. 2016;6(3):421-32. doi: 10.1037/vio00000049

21. Gage AJ, Honoré JG, Deleon J. Short-term effects of a violence-prevention curriculum on knowledge of dating violence among high school students in Port-au-Prince, Haiti. J Commun Healthc [Internet]. 2016 [cited 2018 Nov 01];9(3):178-89. Available from: http://dx.doi.org/10.10 80/17538068.2016.1205300

22. Miller S, Williams J, Cutbush S, Gibbs D, Clinton-Sherrod M, Jones S. Evaluation of the start strong initiative: preventing teen dating violence and promoting healthy relationships among middle school students. J Adolesc Heal [Internet]. 2015 [cited 2018 Jul 2];56(2 Suppl 2):S14-9. Available from: doi: 10.1016/j.jadohealth.2014.11.003

23. Taylor BG, Mumford EA, Stein ND. Effectiveness of "shifting boundaries" teen dating violence prevention program for subgroups of middle school students. J Adolesc Health [Internet]. 2015 [cited 2018 Jul 2];56(2 Suppl 2):S20-6. Available from: doi:10.1016/j. jadohealth.2014.07.004

24. Williams J, Miller S, Cutbush S, Gibbs D, Clinton-Sherrod M, Jones S. A latent transition model of the effects of a teen dating violence prevention initiative. J Adolesc Health [Internet]. 2015 [cited 2018 Nov 01];56(2 Suppl 2):S27-32. Available from: http://dx.doi.org/10.1016/j. jadohealth.2014.08.019

25. McLeod DA, Jones R, Cramer EP. An evaluation of a school-based, peer-facilitated, healthy relationship program for at-risk adolescents. Child Sch [Internet]. 2015 [cited 2018 Nov 01];37(2):108-16. Available from: https://doi.org/10.1093/cs/cdv006

26. Miller E, Goldstein S, McCauley HL, Jones KA, Dick RN, Jetton J, et al. A school health center intervention for abusive adolescent relationships: a cluster RCT. Pediatrics;135(1):76-85. doi: 10.1542/peds.2014-2471

27. Alexander CM, Hutchison AN, Clougher KM, Davis HA, Shepler DK, Ambroise Y. Adolescent dating violence: Application of a u.s. primary prevention program in St. Lucia. J Couns Dev [Internet]. 2014 [cited 2018 Nov 01];92(4):489-98. Available from: https://doi. org/10.1002/j.1556-6676.2014.00175.x

28. Peskin MF, Markham CM, Shegog R, Baumler ER, Addy RC, Tortolero SR. Effects of the it's your game ... keep it real program on dating violence in ethnic-minority middle school youths: A group randomized trial. Am J Public Health. 2014;104(8):1471-7. doi:10.2105/ AJPH.2014.301902

29. Belknap RA, Haglund K, Felzer H, Pruszynski J, Schneider J. A theater intervention to prevent teen dating violence for mexican-american middle school students. J Adolesc Health [Internet]. 2013 [cited 2018 Nov 01];53(1):62-7. Available from: http://dx.doi.org/10.1016/j. jadohealth.2013.02.006

30. Taylor BG, Stein ND, Mumford EA, Woods D. Shifting Boundaries: An experimental evaluation of a dating violence prevention program in 
middle schools. Prev Sci [Internet]. 2013 [cited 2018 Nov 01];14(1):64-76. Available from: doi:10.1007/s11121-012-0293-2

31. Oscós-Sánchez MÁ, Lesser J, Oscós-Flores LD. High school students in a health career promotion program report fewer acts of aggression and violence. J Adolesc Health [Internet]. 2013 [cited 2018 Nov 01];52(1):96-101. Available from: https://doi.org/10.1016/j. jadohealth.2012.04.006

32. Muñoz B, Ortega FJ, Sánchez V. El DaViPoP: Un programa de prevención de violencia en el cortejo y las parejas adolescentes. Apunt Psicol [Internet]. 2013 [cited 2018 Nov 01];31(2):215-24. Available from: http://www.apuntesdepsicologia.es/index.php/revista/article/view/324

33. Foshee VA, McNaughton Reyes HL, Ennett ST, Cance JD, Bauman KE, Bowling JM. Assessing the effects of families for safe dates, a familybased teen dating abuse prevention program. J Adolesc Heal [Internet]. 2012 [cited 2018 Nov 01];51(4):349-56. Available from: http:// dx.doi.org/10.1016/j.jadohealth.2011.12.029

34. Enriquez M, Kelly PJ, Cheng AL, Hunter J, Mendez E. An Intervention to address interpersonal violence among low-income midwestern Hispanic-American teens. J Immigr Minor Health [Internet]. 2012 [cited 2018 Nov 01];14(2):292-9. Available from: doi:10.1007/ s10903-011-9474-5

35. Hamby S, Nix K, De Puy J, Monnier S. Adapting dating violence prevention to francophone switzerland: a story of intra-western cultural differences. Violence Vict [Internet]. 2012 [cited 2018 Nov 01];27(1):33-42. Available from: https://doi.org/10.1891/0886-6708.27.1.33

36. Pick S, Leenen I, Givaudan M, Prado A. “I want to I can ... prevent violence \{"\}: Raising awareness of dating violence through a brief intervention. Salud Ment [Internet]. 2010 [cited 2018 Nov 01];33(2):153-60. Available from: http://www.medigraphic.com/pdfs/salmen/sam2010/sam102f.pdf

37. Wolfe DA, Crooks C, Jaffe P, Chiodo D, Hughes R, Ellis W, et al. A school-based program to prevent adolescent dating violence. Arch Pediatr Adolesc Med [Internet]. 2009 [cited 2018 Nov 01];163(8):692-9. Available from: doi:10.1001/archpediatrics.2009.69

38. Garrido V, Casas M. The prevention of dating violence in youth: the «Mask of Love» workshop. Rev Educ [Internet]. 2009 [cited 2018 Nov 01];349:335-60. Available from: http://www.revistaeducacion.mec.es/re349/re349_16.pdf

39. Moskovic CS, Guiton G, Chirra A, Núñez AE, Bigby J, Stahl C, et al. Impact of participation in a community-based intimate partner violence prevention program on medical students: a multi-center study. J Gen Intern Med. 2008;23(7):1043-7. doi: 10.1007/s11606-008-0624-y

40. Jaycox LH, McCaffrey D, Eiseman B, Aronoff J, Shelley GA, Collins RL, et al. Impact of a school-based dating violence prevention program among latino teens: randomized controlled effectiveness trial. J Adolesc Health [Internet]. 2006 [cited 2018 Nov 02];39(5):694-704. Available from: doi:10.1016/j.jadohealth.2006.05.002

41. Foshee VA, Bauman KE, Ennett ST, Suchindran C, Benefield T, Linder GF. Assessing the effects of the dating violence prevention program "Safe Dates" using random coefficient regression modeling. Prev Sci. 2005;6(3):245-58. doi: 10.1007/s11121-005-0007-0

42. Foshee VA, Bauman KE, Ennett ST, Linder GF, Benefield T, Suchindran C. Assessing the long-term effects of the Safe Dates program and a booster in preventing and reducing adolescent dating violence victimization and perpetration. Am J Public Health. 2004;94(4):619-24.

43. Foshee VA, Bauman KE, Arriaga XB, Helms RW, Koch GG, Linder GF. An evaluation of safe dates, an adolescent dating violence prevention program. Am J Public Health [Internet]. 1998 [cited 2018 Nov 02];88(1):45-50. Available from: https://www.ncbi.nlm.nih.gov/pmc/articles/ PMC1508378/

44. Avery-Leaf S, Cascardi M, O'Leary KD, Cano A. Efficacy of a dating violence prevention program on attitudes justifying aggression. J Adolesc Health. 1997;21(1):11-7.

45. Macgowan MJ. An evaluation of dating violence prevention program for middle school students. Violence Vict. 1997;12(3): 223-35.

46. Lavoie F, Vézina L, Piché C, Boivin M. Evaluation of a prevention program for violence in teen dating relationships. J Interpers Violence [Internet]. 1995 [cited $2018 \mathrm{Jul}$ 2];10(4):516-24. Available from: https://doi.org/10.1177/088626095010004009

47. Carlos DM, Beatriz CA, Silva JL, Fernandes MD, Leitão MNC, Silva MAl, et al. [School-based interventions for teen dating violence prevention: integrative literature review]. Rev Enferm Ref [Internet]. 2017 [cited 2018 Nov 02];4(14):133-46. Available from: doi:10.12707/RIV17030\} Portuguese.

48. Casemiro JP, Fonseca ABC, Secco FVM. [Promoting health in school: reflections based on a review of school health in Latin America]. Cien Saude Colet [Internet]. 2014 [cited 2018 Jul 2];19(3):829-40. Available from: http://dx.doi.org/10.1590/1413-81232014193.00442013 Portuguese.

49. Egry EY, Fonseca RMGS, Oliveira MAC, Bertolozzi MR. Nursing in collective health: reinterpretation of objective reality by the praxis action. Rev Bras Enferm [Internet]. 2018 [cited 2018 Jul 2];71(suppl 1):710-5. Available from: http://dx.doi.org/10.1590/0034-7167-2017-0677

50. Moore A, Sargenton KM, Ferranti D, Gonzalez-Guarda RM. Adolescent dating violence: supports and barriers in accessing services. J Community Health Nurs [Internet]. 2015 [cited 2018 Nov 02];32(1):39-52. Available from: doi: 10.1080/07370016.2015.991668 